\title{
A compliance fontossága a táplálásterápiában
}

\author{
Mikulka Ilona dr. \\ Házi gyermekorvosi rendelo, Vásárosnamény
}

\begin{abstract}
A betegség okozta alultápláltság az alapbetegség és a nem megfelelő táplálkozás együttes következményeként alakul ki. A betegséghez kapcsolódó kezeletlen alultápláltság súlyos következményekkel jár, amelyek jelentősen rontják a fizikális-lelki egészséget és múködést, valamint az alapterápia hatékonyságát, továbbá a betegség kimenetelét. Múködő gastrointestinalis rendszer megléte mellett a táplálásterápia elsődleges választandó formája az iható tápszer. Mint minden más terápiánál, a táplálásterápia esetén is rendkívül fontos kérdés a compliance, amelyet nagymértékben befolyásolnak olyan tényezők, mint az állag, íz, illat, elfogyasztandó mennyiség, illetve az esetlegesen jelentkező mellékhatások. Az esetleírás célja annak bemutatása, hogy a beteg compliance-ét meghatározó tényezők figyelembevételével megválasztott tápszerrel a betegség okozta alultápláltság sikeresen kezelhető. Orv. Hetil., 2016, 157(15), 596-598.
\end{abstract}

Kulcsszavak: alultápláltság, táplálásterápia, compliance

\section{Importance of compliance in nutritional management. Case report}

Disease-related malnutrition is usually caused by the joint action of the underlying disease itself and dietary deficiency. The consequences of malnutrition, if left untreated, are serious, causing a marked decline in physical and psychological health and function, and an increased rate of complications and decreased effectiveness of the medical treatments. In case a functional gastrointestinal tract is present, the recommended form of nutritional management is the use of oral nutritional supplements. However, just like to any other therapy, compliance to oral nutritional supplements is highly influenced by the consistency, taste, smell, volume consumed, and side effects. The aim of the present case report is to illustrate that nutritional management is a successful and effective treatment option of disease-related malnutrition when the selection of the oral nutritional supplement takes into consideration patient's preferences as well.

Keywords: malnutrition, nutritional management, compliance

Mikulka, I. [Importance of compliance in nutritional management. Case report]. Orv. Hetil., 2015, 157(15), 596598.

(Beérkezett: 2016. febuár 4.; elfogadva: 2016. február 22.)

\section{Rövidítések}

COPD = krónikus obstruktív tüdőbetegség; IBD = gyulladásos bélbetegség

A betegséghez kapcsolódó alultápláltság (azaz a betegség okozta alultápláltság) világszerte ismert és aluldimenzionált probléma $[1,2]$. Mivel a betegséghez kapcsolódó alultápláltság károsan hat a különböző szervrendszerekre, továbbá súlyos fizikális és pszichoszociális következményekkel járhat, valamennyi egészségügyi ellátórendszernek kiterjedten kell foglalkoznia az állapot korai felismerésével és kezelésével/megelőzésével.

A betegséghez kapcsolódó alultápláltság a nyugati országokban általában az alapbetegség (például daganat, krónikus obstruktív tüdőbetegség [COPD], gyulladásos bélbetegség [IBD], időskori kognitív zavar, Alzheimerbetegség) és a nem megfelelő táplálkozás együttes következményeként alakul ki [3]. Ennek következtében a kezelésnek nemcsak az alapbetegségre ható terápiákat, hanem a táplálásterápiát is tartalmaznia kell. A betegséghez kapcsolódó kezeletlen alultápláltság súlyos következményekkel jár, amelyek jelentősen rontják a fizikális és 
lelki egészséget és múködést. Az alultápláltság károsan befolyásolja az alapbetegségből történő felépülést, az alapbetegség kezelésre történő javulását, a sebgyógyulást, a szövődmények (fertőzés, felfekvés stb.) gyakoriságát, a prognózist, a mortalitást, a kezeléssel szembeni toleranciát, az életminőséget és az egészségügyi ellátórendszer igénybevételét (háziorvosi vizitek, kórházi tartózkodások száma és hossza) $[4,5]$.

Iható tápszereket általában azzal a céllal írnak fel, hogy a beteg tápláltsági állapotának és a terápiás mellékhatások elviselésének javításával kedvező irányba befolyásolják a betegség klinikai kimenetét. Azonban mint minden más terápiánál, a táplálásterápia esetén is rendkívül fontos kérdés a compliance, hiszen az előbb említett célokat csak akkor sikerülhet elérni, ha a beteg a felírt tápszert el is fogyasztja. Az iható tápszerekkel kapcsolatos compliance-t pedig nagymértékben befolyásolják olyan, a hatékonyságtól független tényezők, mint az állag, íz, illat, elfogyasztandó mennyiség, illetve az esetlegesen jelentkező mellékhatások (például puffadás, teltségérzés, hasmenés). Éppen ezért a fogyasztásra kész iható tápszerek esetében a tápszer beteg által történő elfogadása és az elfogyasztott mennyiség gyakran szuboptimális, mert a már amúgy is csökkent étvágy mellett a betegnek olyan tápszert kell(ene) fogyasztania, amelynek állaga, illata és /vagy íze a beteg számára nem kellemes, vagy fogyasztása kellemetlen mellékhatásokkal jár. Ezekhez a nehézségekhez járul hozzá sok esetben a csökkent vagy megváltozott ízérzés, amely a compliance-t tovább ronthatja [6]. Ezeket a tényezőket a hatékony, iható tápszerekkel folytatott táplálásterápia biztosításához feltétlenül figyelembe kell venni.

\section{Esetismertetés}

A 13 éves fiúgyermek ikerterhességből, a 35. gesztációs héten B magzatként, Apgar 1 státuszban született. Újszülöttkorban pneumothorax, haemorrhagi cerebri, hydrocephalus, epilepszia miatt kezelték. Hónapokig volt kórházban, 2 hónapos korban ventriculoperitonealis sönt beültetése történt.

A gyermeknek súlyos maradványtünetei vannak, motoros és mentális fejlődése vontatott, izomzata tetraspasticus-pareticus, önálló helyzetváltoztatásra képtelen. Súlyos állapota miatt rendszeres neurológiai és gasztroenterológiai gondozásban részesül.

Táplálása rendkívül nehéz, szilárd táplálékot fogyasztani nem képes, a folyékony-pépes ételeket sem fogadja el mindig, az ízekre különösen érzékeny. A táplálási nehézségek következtében nála fehérjehiányos alultápláltság, cachexia alakult ki. Testsúlya 13 évesen $16 \mathrm{~kg}$. A malnutritio kezelésére évek óta tápszeres kezelésben részesül, többféle tápszert is kapott. Ezek közül egyeseket ízük, másokat a jelentkező mellékhatások (hányinger, székrekedés) miatt nem volt hajlandó elfogyasztani, illetve volt, amelynek elérhetősége megszünt.
Egy éve gasztroenterológus javaslatára MedDrink Plus tápszert kapott, amelyet nagyon szívesen fogyaszt, különösen szereti a vaníliás és az ízesítés nélküli változatot. A napi 3 doboz tápszer rendszeres elfogyasztása a gyermek tápláltsági állapotát jelentősen javította, l év alatt körülbelül 1 kg-ot hízott, azaz mintegy 7\%-os testsúlynövekedést sikerült elérni (1. ábra). Emellett székrekedése is jelentősen csökkent.

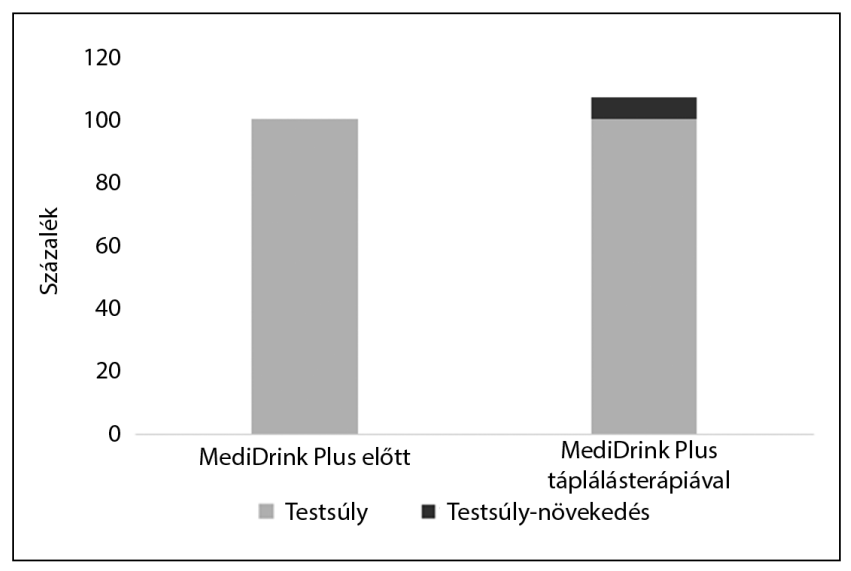

1. ábra Egyéves MediDrink Plus táplálásterápia hatására mintegy 7\%-os testsúlynövekedés következett be

\section{Megbeszélés}

Az iható tápszerekkel kapcsolatos compliance-t vizsgáló 46 klinikai tanulmány összevont elemzése szerint az iható tápszerekkel kapcsolatos compliance átlagosan $78 \%$, ami jó közelítéssel megfelel a különböző gyógyszeres terápiák esetén látott compliance-értékeknek. A compliance értékét jelentősen befolyásolja az iható tápszer energiatartalma: a magas energiatartalmú $(\geq 2 \mathrm{kcal} / \mathrm{ml}$ ) tápszerek esetén a compliance szignifikánsan jobb, mint az ennél alacsonyabb (1,5 kcal/ml, illetve $1-1,3 \mathrm{kcal} /$ $\mathrm{ml}$ ) energiatartalmú tápszerek esetén. Ennek nagy valószínúséggel az az oka, hogy a magasabb energiatartalmú tápszerből ugyanannyi kalória beviteléhez kevesebbet kell elfogyasztani [7]. Például napi $600 \mathrm{kcal}$ tápszerrel történő beviteléhez $2 \mathrm{kcal} / \mathrm{ml}$ energiatartalmú tápszerből $300 \mathrm{ml}-\mathrm{t}, 1,5 \mathrm{kcal} / \mathrm{ml}$ energiatartalmú tápszerből $400 \mathrm{ml}-\mathrm{t}, 1 \mathrm{kcal} / \mathrm{ml}$ energiatartalmú tápszerből pedig $600 \mathrm{ml}-\mathrm{t}$ kell a betegnek elfogyasztania.

Gyakran felmerülő kérdés, hogy hosszú ideig folytatott táplálásterápia esetén csökken-e a betegek compliance-e. Az előbb idézett klinikai vizsgálati összefoglaló elemzés nem talált különbséget a compliance-t illetően a rövid ideig (4 nap) és a hosszú távon alkalmazott ( 1 év) táplálásterápiák között [7]. Mivel a krónikus betegségek kapcsán kialakult alultápláltság általában hosszas tápszeres kezelést igényel, ez az eredmény azt mutatja, hogy jól megválasztott táplálásterápia esetében hosszú távon is lehetséges a jó compliance és így a terápia sikerességének biztosítása. 
Az energiatartalom azonban nem az egyetlen tényező, amely befolyásolja a beteg compliance-ét. Egy 109 beteg részvételével folytatott klinikai vizsgálat [6] visszajelzései szerint a betegek szignifikánsan jobban kedvelik a tejfehérje-alapú, mint a gyümölcslétípusú tápszereket $(81,6 \%$ vs. $18,4 \%, p<0,001)$, függetlenül attól, hogy az emésztőrendszeri tolerancia valamennyi tápszer esetében hasonló volt. Amennyiben az édes és a sós gyümölcslétípusú tápszereket külön csoportként kezelték, a sós gyümölcslétípusú tápszerek még kevésbé voltak kedveltek, mint az édes gyümölcslétípusúak.

Jelentősen hatással van az iható tápszerekkel szembeni compliance-re a tápszer íze is. Az előbb említett vizsgálat [6] eredményei azt mutatták, hogy a legkedveltebb íz a kávé, ezt követi az eper, vanília és a csokoládé, kevésbé kedveltek a paradicsom, alma és narancs, a legkevésbé kedvelt pedig az ízesítetlen. Ez utóbbi eredmény nem meglepő, hiszen az ízesítés nélküli tápszerek elsősorban nem közvetlen fogyasztásra készülnek, hanem arra, hogy különböző ételek elkészítésekor használják fel őket, így emelve az étel energia-, fehérje- és egyéb tápanyagtartalmát.

\section{Következtetés}

Elmondhatjuk, hogy mind nemzetközi adatok, mind pedig saját tapasztalatok alapján az iható tápszerek különböző tulajdonságai jelentősen befolyásolják a táplálásterápiával szembeni betegcompliance-t. A magas $(\geq 2$ $\mathrm{kcal} / \mathrm{ml}$ ) energiatartalmú, tejfehérje-alapú, valamint a betegnek is kellemes, szívesen fogyasztott ízű tápszer választása nagyban segítheti a terápiahüséget. Így a jól megválasztott táplálásterápia esetében hosszú távon is lehetséges a jó compliance, amely nagyban hozzájárul a táplálás sikerességéhez, ezen keresztül pedig a jobb tápláltsági állapot, kevesebb szövődmény és kedvezőbb betegségkimenetel eléréséhez.
Anyagi támogatás: A közlemény megírása anyagi támogatásban nem részesült.

A szerző a cikk végleges változatát elolvasta és jóváhagyta.

Érdekeltségek: A szerzőnek nincsenek érdekeltségei.

\section{Irodalom}

[1] Correia, M. I., Waitzberg, D. L.: The impact of malnutrition on morbidity, mortality, length of hospital stay and costs evaluated through a multivariate model analysis. Clin. Nutr., 2003, 22(3), 235-239.

[2] Meijers, J. M., Halfens, R. J., van Bokhorst-de van der Schueren, M. A., et al.: Malnutrition in Dutch health care: prevalence, prevention, treatment, and quality indicators. Nutrition, 2009, 25(5), 512-519.

[3] Naber, T. H., Schermer, T., de Bree, A., et al.: Prevalence of malnutrition in nonsurgical hospitalized patients and its association with disease complications. Am. J. Clin. Nutr., 1997, 66(5), $1232-1239$.

[4] Martyn, C. N., Winter, P. D., Coles, S. J., et al.: Effect of nutritional status on use of health care resources by patients with chronic disease living in the community. Clin. Nutr., 1998, $17(3), 119-123$.

[5] Löser, C.: Malnutrition in hospital: the clinical and economic implications. Dtsch. Arztebl. Int., 2010, 107(51-52), 911-917.

[6] Darmon, P., Karsegard, V. L., Nardo, P., et al.: Oral nutritional supplements and taste preferences: 545 days of clinical testing in malnourished in-patients. Clin. Nutr., 2008, 27(4), 660-665.

[7] Hubbard, G. P., Elia, M., Holdoway, A., et al.: A systematic review of compliance to oral nutritional supplements. Clin. Nutr., 2012, 31(3), 293-312.

(Mikulka Ilona dr., Vásárosnamény, Erkel u. 1., 4800 e-mail: mikulka51@citromail.hu)

Az Orvosi Hetilap 2016, 157, 400. oldalán (10. szám) megjelent OH-Kvízre négy helyes megfejtés érkezett.

A beküldők: Dr. Bíró László (Budapest), Dr. Janik Leonárd (Budapest), Dr. Pallos Ágnes (Budapest) és Dr. Somogyi Erzsébet (Miskolc)

A nyerteseknek szívböl gratulálunk.

A nyereményüket - egy, az Akadémiai Kiadó webáruházában kedvezményes vásárlásra jogosító kupont - e-mailen küldjük el. 